\title{
DIDACTIC LIMITATIONS OF CONSTRUCTIVISTIC LEARNING MODEL IN TEACHING ${ }^{1}$
}

\author{
Prof. Grozdanka Gojkov, PhD \\ Preschool Teacher Training College "Mihailo Palov" Vrsac \\ Teacher Training Faculty, Belgrade, \\ Teaching Department, Vrsac (Serbia) \\ e-mail: ggojkov@hemo.net
}

\begin{abstract}
A b stract
At the outset the paper outlines the dominant meta-theoretical tendencies in didactics, in order to shape their frames along with contemporary didactic trends based on them. The attention will then be paid to constructivistic perspective, as well as epistemological theory which are in the grounds of learning in teaching, i.e. selforganized and biographically determined process of knowledge construction. Efforts will also be made at considering didactic consequences of constructivistic perspective, i.e. the didactics of enabling. Special accent will be put on the reaches and limitations of constructivism, according to the argumentation based on the findings of explorative empirical researches.
\end{abstract} teaching

Key words: enabling didactics, limitations of constructivistic learning model in

The reflections in the title of the paper impose the issue of outlining the dominant and rising tendencies in meta-theoretical spheres, before all the methodology of pedagogy, as a frame determining the field on which the contemporary pedagogical trends have been grounded. What follows are didactical consequences of, before all, constructivistic paradigm.

Constructivistic paradigm, as an epistemological theory defining learning as active, self-organized and biographically determined process of knowledge constructions, has offered new impulses to didactics, "didactics of enabling" considered to have an advantage over "didactics of teaching". According to many didactics, constructivism does not rule out the traditional methods and forms of teaching and learning, in spite of that fact that it is based on the attitudes on learning as self-organized and self-responsible process. These attitudes have been supported by the outcomes of the research in the field of cognitive psychology. ${ }^{2}$ What has also been emphasized as

\footnotetext{
${ }^{1}$ The paper was written within the project supported by the Ministry of Science of the Republic of Serbia, No 179036 for the period 2011-2014.

${ }^{2}$ Weinert, F./Mandl,H., Psychologie der Erwachsenbildung, Gottingen, 1997.
} 
significant in the relevant literature are the outcomes showing that constructivistic procedures do not develop in all students active, constructive, self-organized processes in learning and in view of all contents and aims; therefore these researchers have advocated for the so called "moderate constructivism" and suggested coexistence between construction and instruction. ${ }^{3}$ Our intention is not to give further attention to the explication of other forms of didactic implications of the application of constructivistic paradigm; we would rather remain on the statement that the application of constructivistic paradigm at the level of teaching methodology means that the advantage is generally given to the procedures of independent knowledge acquisition in encouraging environment and learning situations. Therefore more space is given to the methods such as: project teaching, research in natural environment, creative methods, learning through discovery, small group work, etc, having in mind that they encourage independent student's activity. However, not one of these methods is in itself either good or bad, since its suitability depends on the aim and the contents, as well as on the context, situation, student and teacher.

From constructivist perspective, the role of the teacher has also been changing. The basic aspect of this role refers to the preparation of the context, i.e. creation of a stimulating environment, including preparation of learning materials through various canals and creation of social situations for learning, as well as ways in which an individual construes recognition of reflections and understanding of the problems arising in learning. The main features of a teacher have been emphasized: self-reflexivity, encouraging others, being careful and non-directive. ${ }^{4}$

Before we turn to the limitations of constructivistic didactic models, we will only mention that most of them could be classified in socially-interaction conceptions of education and teaching characterised by a number of variants and a wish to overcome the negligence of social controversies, crises, the clashes of values, norms and interests, having in mind that they are a part of reality and can be expected in a society developing pluralistic democracy. Just like program-centred and learner-centred education, this type of education is focused on social community. It seems significant that the application of this and other conceptions (personal, cognitivistic, technological) and their variants implies the respect of age and the type of education. As a consequence of the complexity of the teaching process and the need for the conceptions ${ }^{5}$ to be in harmony with this complexity, the teaching models met in practice are almost as a rule a combination of elements taken from a number of conceptions, even those which are not close or are even confronted.

In pedagogy constructivism has been considered a tradition, or the so called pedagogy of "construction", constructivistic pedagogy, or according to some authors "alternative pedagogy", created under the influence of Emmanuel Kant at the end of the $18^{\text {th }}$ century. In his work "Critique of Pure Reason" Kant maintains the standpoint that knowledge depends on the sense, but he does not dismiss reason. Only reason, according

\footnotetext{
${ }^{3}$ Ibid

${ }^{4}$ Špoljar, K., Konstruktivistička paradigma u istraživanju i unapređivanju prakse i odgoja i obrazovanja; in: Didaktični in metodični vidiki nadaljnega razvoja izobraževanja, Maribor; 1999.

5 Trebješanin, B. i Lazarević, D. (eds.), Savremeni osnovnoškolski udžbenik, Zavod za udžbenike i nastavna sredstva, Beograd, 2001.
} 
to Kant, has the conditions required to interpret what we perceive of the world. The psychology at the end of the $19^{\text {th }}$ century relied on this idea, giving a significant role to the subject in the cognitive development (an individual's knowledge constitutes the determining factor of learning). This movement has since been amplified under the name of constructivism. Based on the spontaneous needs and "natural interests" of individuals, this epistemology advocates free expression, creativity and the knowledge of subjects: how to acquire knowledge, how to master learning strategies. In other words, in the theories grounded on this epistemology, it is significant to reveal, or emphasize the importance of the feeling of someone's ways in the act of learning (metacognition). A person is no longer satisfied with the acceptance of raw, unprocessed data, but (s)he chooses and assimilates them. The construction of knowledge is operated largely by action and the expression of the student's representations. The so called centres of interests in teaching, as well as "active methods" were built on this learning model, especially at the end of 1960ies (in Serbia later, being popular even today).

A standpoint is significant that constructivistic pedagogy (i.e. constructivistic didactics) has several aspects. Gagne and Bruner place the stress on the "associations" to be established between external information and the structure of thought. Ausbel, Novak and others were more explicit and talked of "cognitive points" at the end of the sixties. Gerald Shaefer has suggested the idea of associate chains in his heuristic "zigzag" model, while Piaget, having borrowed the concepts of "assimilation" and "accommodation" from developmental and biology of evolution, made his own contribution with the notion of adjustment, i.e. the modification of organs at biological level or intellectual instruments at the cognitive level, claiming that in the procedure of knowledge assimilation, the subject has to be able to constantly adjusts his/her own way of thinking to the demands imposed by the situation.

\section{The limitations of constructivist models}

The previous text has merely outlined some constructivist models. We refer the reader to other texts for deeper thought on the importance of early constructivistic models and for reflecting on the specific learning approaches ${ }^{6}$ and we would now turn to the criticism nowadays being addressed to constructivism, having in mind that what has still been intensively stressed is the issue of the relation among concepts in certain learning theories.

The early constructivist models have been criticized for being too simple to describe multiple learning mechanisms. More severe critics have stated that, the farther the situations are from the mastered knowledge, the more individuals use primitive reasoning strategies, while it is considered that what we call a "conception" of the situation is put in the second plan in comparison to the way of operating. By limiting oneself to describing general functioning and states of equilibrium, these early models take no account of the processing of specific situations by learners or all the inferences they may make from the information they have available.

${ }^{6}$ Gojkov, G., Od konstruktivizma do alosteričnog modela učenja, Zbornik Katedre za pedagogiju Filozofskog fakulteta u Novom Sadu, sveska 17, Novi Sad, 2002. 
So, the essence of the objections to constructivists is that they neglect the fact nothing is immediately accessible in learning. The critics have emphasized that knowledge is not appropriated by reflective abstraction as Piaget supposed, for the learning of concepts or procedures, new information is rarely inscribed on the line of mastered knowledge; on the contrary, that is rather an obstacle on the cognitive and emotional planes. It is considered that deconstruction of the learner's concepts should be a previous stage, which is not easy, having in mind that the learner does not let her/himself be so easily deprived of the pre-verified competence, which is the only tool at her/his disposal (serving as a framework for interpretation).

In spite of the fact that many authors have believed in constructivistic models as promising ones, there are numerous objections voiced to it. There are estimations according to which constructivists isolate an individual learner, not paying sufficient attention to environment. Another criticism refers to the fact that they place the stress on the cognitive capacities alone, minimizing the place and the role of the environment. Majority of early constructivists managed to ignore the fact that development takes place inside a society, neglecting the fact that environment nevertheless helps to give meaning to situations.

Constructivism critics have also pointed out that as far as the emotional sphere is concerned, if it is not denied, neither has it been taken into account, for the lack of a model to make explicit the links between the cognitive and the affective. However, feelings, desires, passions play a strategic role in the act of learning.

In other words, the general criticism refers to the fact that constructivists seem to be largely silent on the contexts and conditions that favour learning, which is frustrating when one is concerned with education or mediation. ${ }^{7}$ Didactics have noticed that at their best constructivistic conceptions put forward the idea of "maturation", i.e. natural development or "equilibration", pointing out the statement that the subject still has to realise what (s)he is learning and therefore (s)he has to find it interesting. Having noticed the gap, post-Piaget school made a step forward envisaging "co-action" or "cognitive conflict". It has been considered that these models are still poor in the face of the complexity of reality. The outside world does not teach an individual directly what (s)he is supposed to learn. An individual has to invent meaning from the environment of inevitable parameters.

What has been stated in the paper is in favour of the thesis that we should go beyond constructivism, i.e. that we should make an attempt at bypassing constructivism, at least the one which is present in the existing models of teaching and learning. We aimed at creating a context for the question which is in the basis of practical consequences of didactic models and refers to the following: is it possible to build didactical models according to constructivism, or, are the new models, relying on constructivism more promising than the previous traditions.

According to contemporary literature, we are not lonely in our doubts in the possibilities to reduce learning in all its complexity to a single model. Namely, it is considered a pleasant delusion that the advances in the research on neurons will provide a good understanding of psychological mechanisms. An organized system, like learning,

\footnotetext{
${ }^{7}$ What's new about learning? Http://www.concord.Org/inti/cbe/papers/giordan-learning. html
} 
is not a simple whole and it is more than the sum of its parts. In this whole, the student, the teacher, the contents... are not independent levels and, in methodological sense, to stop at a single moment or a simple analytical procedure inevitably leads to a change of meaning of the object of study. Furthermore, this means that there is a little chance of finding learning by concentrating just on the neurons, information processing or even the level of representations. Moreover, construction of a model apart from everyday situations imposes a demand for their practical verification, i.e. empirical validation.

What also seems important to us are the observations on integration, coming from a process of organization (reorganization) and regulation of previous elements in interaction with new data which leads to their eventual metamorphosis. It is further considered that the emergence of new knowledge is only possible with the presence student's awareness, his/her intention to learn, his ability to manage to modify his mental structure and reformulate (elaborate) it completely; furthermore, the emergence of new knowledge is only possible if the learner is aware that it will help him/her at the level of explanation, expectation or actions to be taken (metacognition). The affective, the cognitive and meaning are thus intimately linked in multiple regulations; learning depends on the context, due to the fact that it takes place in socio-cultural environment.

We could conclude that learning is a phenomenon emerging from the meeting of neuron potentials, memorised experiences of a person and a direct or mediated environment which allow their constant actualization. Each individual has very precise beliefs about the world around her/him, and sets operational procedures in motion. Nevertheless, if (s)he has none on the question tackled, (s)he manipulates other ideas on the matter, which interfere strongly with the question. This system of thoughts is known as a conception. Its task is to guide the way in which the learner decodes the information and formulates her/his new ideas. And so learning is not adding new information. Apprehending new knowledge is integrating in into a structure of thought which is already "in place" and which, paradoxically, rejects it. It is through one's own knowledge, existing prior to education situation (but a student is capable of mobilising in this situation), that the student is capable of decoding new data and possibly contrasting them. ${ }^{8}$

Previous theories, as well as the didactic conceptions and the models built on them, have not managed to ultimately explicate the issue of integration of various data within a conceptual framework; as a consequence the matter of metacognition significance (its influence on operability and mobility of knowledge) has not been sufficiently considered.

It is also important that there are still a number of points that have remained unexplained which could contribute to understanding of the conditions influencing learning, although mental activities are viewed as data processing (genetic theories) or even as hierarchical data processing (cognitive theories) which can integrate new data into conceptual system of learners. Understanding of cognitive mechanisms is considered necessary, but it is insufficient in the attempt at understanding a context or nature of didactic strategies. Therefore it is nowadays a case that there are new didactic

\footnotetext{
${ }^{8}$ What's new about learning? Http: //www.concord.Org/inti/cbe/papers/giordan-learning. html
} 
models at the contemporary didactic scene ${ }^{9}$ which are considered unique, having in mind that their aims are didactic, since they try to solve the problems related to learning, taking didactic environment into consideration, along with the borrowed elements of previously discussed theories.

A research on metacognitive abilities, attempting at empirical validation of instructional approach to the research on metacognitive abilities, as well as on the encouragement, i.e. learning in teaching has been undertaken in order to consider the possibilities to empirically validate the above sketched theoretical - epistemological ground, creating a space for making attempts to gain insight into reaches of their practical use. Namely, an attempt has been made at getting to the elements for argumentation of the standpoint that some of the theoretically conceived elements are used as grounds for a strategy change within learning in teaching. The way to do this seemed to be an explorative research aiming at answering the following question:

- to what an extent constructivism can be considered a new paradigm in didactics and can it be taken as a step further and a principle of change in the system of education?

The explication of this issue indirectly gives answers to the following questions:

- do the changes of the roles of teachers and learners, as well as the nature of learning activities have to imply a curriculum based on activities through which a pupil looks for the elaboration of initial answers;

- to what an extent does the pluralization of didactic scene give the teachers competences of a conductor, an associate, a co-researchers who incites the creation of ideas;

- where is the line where the curriculum based on activities is transformed into research activities by the means of attempt and error;

- do and in what sense tolerated attempts, as a part of learning, contribute to the development of learner's autonomy;

- to what an extent are the didactic views on the models of learning in teaching in confrontation with constructivism as epistemological ground of didactics and what consequences does this have for the curriculum;

- can Sternberg's triarchic theory of intelligence be considered sufficient to "cover" psychological substance of metacognition, which would be regarded as an important element of metatheoretical ground of curriculum;

- does the constructivistic definition of learning as a process of personal construction of meanings mean what has until now been seen as a solution...

The explorative research, of course, cannot give answers to all these questions, but its outcomes might be in a sense used to provoke reflection on them. Our intention was to see to what an extent the instructional approach to the research on intellectual processes, together with the effects of metacognitive components (built into neoVygotskian courses of process diagnostics) can be considered adequate for gaining more

${ }^{9}$ For more detailed insight into contemporary didactic models see: The Allosteric Learning Model and Current Theories about Learning http: //www.unige.ch/fapse/ SSE/teachers/giordan/ LDES/ anglais/allosGB/tha-ppGB.html 
certain picture on learning process and functioning. According to this, we could make conclusions on the extent metacognition can be encouraged by didactic instructions.

Our standpoint is that didactic instructions can encourage metacognitive abilities contributing to overall knowledge on didactic encouragement of meta-components. Let's mention here the fact that metacognitive abilities are a field where psychology and didactics have recently been brought significantly closer together. We would also like to turn to the statements arising from fundamental research on learning process and learning instructions in a classroom paying special attention to the context. So, "contextual approach" has shifted the focus from studying abilities, learning and results to studying the capacity of a learner to regulate his/her learning, as well as to the capability of a teacher to create a suitable learning setting. ${ }^{10}$

The reason we have chosen such an approach to the issue we are dealing with is incited but the fact that cognitive system and its development has in the last few decades been viewed as a self-modifying system. At the same time, it is often the case that learning is viewed from the same angle (self-regulated learning). This perspective of pedagogic psychology has, along with the acceptance of contextual approach to intellectual abilities (Sternberg), encouraged those dealing with didactics to search for new mechanisms to enable gaining of knowledge on abilities and to develop abilities into cognition. The research has certainly been driven by the outcomes of the studies claiming that the specialized knowledge of students, the use of cognitive strategies and self-regulation have an important influence on academic learning.

At this point we are heading towards the aim of the explorative research. Its essence refers to the attempt to empirically validate (by the means of critical consideration and theoretical analyses) the frames emphasizing a new vision of postmodern didactics as an omen of contemporary transformation of educational systems.

The ideas of participation, autonomy, communication, etc. in education are integrated in the systems of education in entire Europe. We are interested in what principles would be significant for the strategy to be used to implement changes and to build models for real processes of decision making.

Metacognition is important for the issues the paper is dealing with since it has a key position in the entire cognitive development. Even though it has been acknowledged that its explanatory potential has only been guessed, yet to be found out (although it is connected with the key segments of personality: self, self-perception, self-awareness), it still is a challenge for didactics, too.

It is a fact that psychology, aware of the complexity of the nature of cognitive functioning and intelligence has come closer to instructional approach, i.e. didactics. Through Sternberg's analysis of intellectual processes, cognitive correlates and the analysis of cognitive components psychology has given the cognitive training approach the status of a new methodological approach, having characteristics of didactical approach with the transfer paradigm in its grounds. This leads us to didactical space

${ }^{10}$ For a broader discussion on the term of metacognition and its relation to didactics and instructional approach as a new research paradigm see: G. Gojkov, Didaktički aspekt metakognicije darovitih, "Pedagoška stvarnost", Novi Sad, br. 1-2, 2002. 
where intellectual processes are to be decided upon according to the ways of subject's thinking during problem solving.

The previous statement includes a possibility to reflect on the outcomes of the research from the angle of instructional approach in order to give more certain picture on functioning and processes of learning. Our intentions here are not directed to so farreaching conclusions. Our task is far more modest. We are to consider a relation between didactic instruction and metacognitive ability, in order to come to a conclusion to what an extent metacognitive abilities can be encouraged.

We have already dealt with the problem in our previous studies. ${ }^{11}$ The underlying issue here is a possibility to use instructional approach in the study on learning process. A step closer to the practical aim is a search for metacognition identity and possibility to encourage its development. Practical consequences are numerous. ${ }^{12}$ Some of them are integrated in the documents directing the first steps of educational reform in Serbia. ${ }^{13}$

\footnotetext{
${ }^{11}$ See the following texts: G. Gojkov, Didaktički aspekt metakognicije darovitih, published in the book of Collected articles at International Conference with a theme: Didaktični in metodični vidiki prenove in razvoja izobraževanja, Maribor, 2001; as well as in a modified version in "Pedagoška stvarnost", Novi Sad, 2002. and in the Book of Collected Articles at the 8th Conference of the European council for high ability - Development of Human Potential: Investment into our Future, Rodos, 2002. (under the title: Didactics of metacognition).

${ }^{12}$ For twenty years now a race for education and research results could be noticed, closely connected to individual and social evaluation and the problems related to this are, among others, essential issues of pedagogy, i.e. didactics. One of the dimensions of these matters refers to the fact that nowadays knowledge in the world is doubled each 5 to 8 years. This is an additionally burdened by the awareness that it is difficult to foresee what is basic knowledge to be needed in the following twenty or fifty years. Consequently, there are standpoints that the purpose is not to completely master the knowledge in a scientific discipline, i.e. field (a subject matter in teaching), but it is considered significant to provide each individual with an opportunity to gain certain culture through specific field (subject matter) learning. So, it has become essential to stimulate each person to become open and able to acquire new knowledge.

${ }^{13}$ The commission for the development of school program has in the working version of the document "Strategy of Curriculum Development in Mandatory and Secondary Education" (Belgrade, 2002) anticipated educational fields as starting points for curriculum design:

- social sciences, philosophy and culture

- language and communication

- mathematics, sciences and technology

- art

- physical education and health culture.

The explication for the introduction of the stated educational fields is offered in the establishment of the necessary coherence between educational process and the system of education. Namely, educational fields should overcome the domains of specific teaching subjects with further establishment of horizontal and vertical connectedness within curriculum. The document in question has not explicitly given theoretical starting points of development strategy for curriculum design, but it remains, according to already mentioned educational fields, as one of the elements of the strategy for developing and structuring a curriculum, to be figured out that constructivism, as epistemological theory, is an underlying point here, i.e. metatheoretical grounds of the development of future curricula. Such a conclusion has been drawn according to the fact that the global changes in teaching organization refer to the relativization of the classical teaching principle (the lines dividing particular subjects have been fading and disappearing, i.e. it is not insisted on persistent respect of thematically conceptual
} 
All the stated has imposed new demands on didactics, making it search for the new models of learning in teaching. One of the attempts has been discussed in the earlier papers of the author of this text, and will not be dealt with here. It will be only outlined in the discussion, putting it in a relation to previous approaches to learning in the attempt at considering its reaches from the angle of the standpoints expressed in the introduction of the paper.

Nevertheless, we will once again take a look at constructivist models. Early constructivist models are significant, having in mind that they have advocated the viewpoint that learning is considered neither a result of the traces left by sensory stimulations on student's spirit nor it is a result of conditioning which appears under the influence of environment.

On the other hand, these models are too simple to describe multiple learning mechanisms. The criticisms of these conceptions have pointed out that, the farther the situations are from the mastered knowledge, the more individuals use primitive reasoning strategies. It is also considered that what is involved is not only the way of operating, but what we call a "conception" of the situation. Furthermore, it is considered that, at the same time, a type of questioning, a frame of reference or ways of making sense come into play... By limiting oneself to describing general functionings and states of equilibrium ("states"), these constructive models take no account of the processing of specific situations by learners or all the inferences they may make from the information they have available.

According to the previously stated observations, it could be concluded that the essence of the objections to constructivists lies in the fact that they neglect that nothing is immediately accessible in learning. Knowledge is not appropriated by reflective abstraction as Piaget supposed. It is even considered that his view is too optimistic or idealized. For the learning of concepts or procedures, new information is rarely inscribed on the line of mastered knowledge; on the contrary, that is rather an obstacle on the cognitive and emotional planes. It is considered that deconstruction of the learner's concepts should be a previous stage, which is not easy, having in mind that the learner does not let her/himself be so easily deprived of his opinions and beliefs which turn out to be so many competences. At this point we have reached the assumptions of the allosteric model, believing that construction and deconstruction can only be interactive processes. New knowledge is only really installed when the previous knowledge has lapsed. In the meantime, the previous knowledge, the only took at the disposal of the learner, has served as a framework for interpretation.

The cognitivists have these days been criticised for isolating an individual learner, not paying sufficient attention to environment; it is considered that every experience is build in an environment. By placing the stress on the cognitive abilities alone, they minimize the place and the role of the environment with a comment that the majority of constructivists have managed to ignore the fact that development takes place in a

structures academic disciplines within a subject, activities are harmonized with informal sequencing of teaching classes). Suggesting the principles to be built into educational process, the same document, among other things, states the need for education to be grounded on participatory, active and cooperative methods of teaching and active forms of learning... These and other details give arguments in favour of the assumption on previously stated theoretical-epistemological grounds underlying the changes in the educational system. 
society. The critics of constructivism have also pointed out that as far as the affectiveemotional sphere is concerned, if it is not denied by anyone, neither has it been taken into consideration, for the lack of a model to make explicit the links between the cognitive and the affective. However, it is considered that feelings, desires passions play a strategic role in the act of learning.

And so, the general objection to constructivists seem to be that they are largely silent on the contexts and conditions that facilitate learning, which is frustrating when one is concerned with education or mediation. ${ }^{14}$ Didactics state that constructivistic conceptions at their best put forward the idea of "maturation", i.e. natural development or "equilibration", pointing out the statement that the subject still has to realise what (s)he is learning and therefore (s)he has to find it interesting. Having noticed the gap, post-Piaget school made a step forward envisaging "co-action" or "cognitive conflict". It has been considered that these models are still poor in the face of the complexity of reality. The outside world does not teach an individual directly what (s)he is supposed to learn. An individual has to invent meaning from the environment of inevitable parameters.

We shall add several other arguments to be often met in the relevant contemporary literature in favour of the standpoint that we should go beyond constructivism. Only some of them will be dealt with here from methodological angle.

We have witnessed that the didactic traditions and psychological models have remained strongly resistant to investigation. Beyond this, there is a question related to the paradigms of research studies. At present a standpoint has been advocated that we should overcome the cognitivist impasse of a subject faced with an object of study, i.e. that this relation is to be situated in a social context that gives it a meaning. Institutions, moments, tools and resources (as well as their interactions) which encourage or prevent learning are the raw material. Likewise, learning must before all be specifically specified in relation to its neuronic and neuromediator supports.

Our doubts in the possibilities to limit learning in all its complexity to a single model have also been expressed by numerous authors in the literature. Namely, it has been considered that those who suppose that advances in the physical chemistry of neurons will provide a good understanding of psychic mechanisms are under a great delusion: having in mind that it is not possible to deduce the properties of a molecule of water from those of its constituent atoms, it is also not possible for an organized system as learning to consist of the simple sum of its parts; the interactions between the elements and the multiple relations, i.e. regulations create new properties (the whole is more that the sum of its parts, or it is different). As a consequence, the teacher, the student, the school, the neurons are not independent levels. In methodological sense, to stop at a single moment or a simple analytical procedure inevitably leads to the distortion of the object of study. For the issue we are dealing with this further means that there is a little chance of finding learning by concentrating just on neurons, information processing or even the level of representations. Consequently, it is considered that a cognitivist cannot formulate an operational model in a laboratory. The cognitive mechanisms at work in experimental situations are not identical to those mobilised in everyday ones.

\footnotetext{
${ }^{14}$ Ibid
} 
There have been attempts at overcoming the discourse outlined in the previous conceptions and in literature known as transversal procedure (LDES), located at the point of intersection of the constraints arising from the properties of the brain, the background of the learner's system of thought and the possibilities offered by educational situations trying to present the dimensions regulating learning (biological dimension - has homeostatic function); cognitive and socio-cultural dimension (since learning is the insertion of an individual into a complex environment) and affective dimension (since we only learn that we are interested in or what touches us). These three levels regulate each other mutually and simultaneously.

It seems important to mention the viewpoint here that there is not only one possible way to learn. Various ways can at the same time be both complementary and conflicting. What determines learning is not a network of external information interpreted by an individual. The learner is the only true architect of her/his training, but his/her environment is not less important, having in mind that his knowledge progresses when fertile subjective interactions between his mental activities and his environment are put in place. The environment simultaneously stimulates and gives meaning to the process.

In addition to what has already been said, observations seem to be significant that integration comes from the process of organization (reorganization) and regulation of the existing in the interaction with new data, leading to their eventual metamorphosis. It is further considered that the emergence of new knowledge is only possible with the presence student's awareness, his/her intention to learn, his ability to manage to modify his mental structure and reformulate (elaborate) it completely; furthermore, the emergence of new knowledge is only possible if the learner is aware that it will help him/her at the level of explanation, expectation or actions to be taken (metacognition). The affective, the cognitive and meaning are thus intimately linked in multiple regulations; learning depends on the context, due to the fact that it takes place in sociocultural environment.

Consequently, it can be concluded that learning is a phenomenon emerging in the encounter of neuron potentials, memorized experiences of an individual and a direct or mediated environment which allow their constant actualization. Each individual has very precise beliefs about the world around her/him, and sets operational procedures in motion. Nevertheless, if (s)he has none on the question tackled, (s)he manipulates other ideas on the matter, which interfere strongly with the question. This system of thoughts is known as a conception. Its task is to guide the way in which the learner decodes the information and formulates her/his new ideas. And so learning is not adding new information. Apprehending new knowledge is integrating in into a structure of thought which is already "in place" and which, paradoxically, rejects it. It is through one's own knowledge, existing prior to education situation (but a student is capable of mobilising in this situation), that the student is capable of decoding new data and possibly contrasting them. ${ }^{15}$

The intention of the critical tones referring to the theoretical traditions in learning comprehension was not to consider their values and shortcomings in detail. This would certainly not be a simple task, having in mind, before all, that the theories themselves are

\footnotetext{
${ }^{15}$ Ibid
} 
at the level of general principles, to be further developed in detail, establishing links with each other (biology, linguistics, semiology, informational technologies...). Nevertheless, we are outlining the reviews to be found in the literature, as well as the criticisms in order to sketch the issue underlying the subtitle of the paper, referring to the possibility of the adoption of the allosteric learning model, nowadays frequently met in the literature as one of the possible solutions which should take into consideration the students, their conceptual mechanisms, as well as interdependence between selforganization of learning and circumstances. However, before we turn to the attempt at sketching the essence of allosteric model, we will point out several more statements referring to previous theories, commenting the understanding of the learning process and hoping that we well get to better understanding of their shortcomings the allosteric model tries to overcome.

The comprehension of learner thought processes, significant for new didactic models (allosteric and others) respects the attitude that the understanding of scientific knowledge is not a simple differentiation between the verbal elements expressing a thought, as proposed by Vygotsky, nor it is an acquisition of isolated facts, as claimed by Gagne. Beyond the understanding of each element, learning has to refer to whole ideas in response to specific questioning. Furthermore, it is considered that memorizing is not a mechanism of fact storage (academic theories), it rather has the function of structuring.

The above discussed theories (cognitive and others) have nevertheless been aware of the treatment of information and of the effects environment has on learning, but they are not ultimately consequent. The following reasons have been pointed out:

- it is considered that the matter of meaning has not been sufficiently taken into consideration; knowledge will be mobile only if it has a sense, a meaning for the student; not only cognitive structure and reasoning abilities are significant for learning of concepts, but also conceptual structures - individuals who have reached high level of abstraction in certain fields, can reason like beginners when confronted by new contents; student's thought schemes are not operational in a simple and straightforward way; mobilized conceptions involve multiple interactions, questions, operations, semantic frameworks and signifiers offering an interpretation system; furthermore, students have to necessarily connect all these parameters (questions, operations...) in order to construe new knowledge;

- it has also been considered that the elaboration of concepts cannot be limited only to learning of isolated data; elementary processes cannot account for all those aspects, i.e. new elements are not directly integrated into prior knowledge; it has even been considered that prior conceptions are often obstacles to such integration. Data that should promote learning cannot be directly assimilated if it contradicts the existing thought structures, and is therefore often ignored. This explicated the radical mutation of the learner's conceptual network, i.e. it emphasizes the difference in comparison to simple storage; new information, integrated into learner's thought systems, transforms not only the thoughts, but also the problem.

The issue of integrating different data within a conceptual framework has not been solved yet; in fact, the above-mentioned theories have not to a sufficient degree dealt with the matter of relations between concepts, as well as with the issue of the importance of metacognition (its influence on operability and mobility of the owned 
knowledge). A viewpoint is also significant that, even if we assume that mental activities are just information processing activities (genetic theories) or evene hierarchical information processing (cognitive theories) which can integrate new data into conceptual systems of learners, we still lack an understanding about the conditions that facilitate learning. Understanding cognitive mechanisms is considered necessary, but it remains insufficient in order to infer the context or nature of appropriate didactic strategies; therefore it is nowadays a case that there are new didactic models at the contemporary didactic scene which are considered unique, having in mind that their aims are didactic, since they try to solve the problems related to learning, taking didactic environment into consideration, along with the borrowed elements of previously discussed theories. ${ }^{16}$

Let us dedicate another moment to the constructivistic perspectives as didactic paradigms. Numerous authors, with Hilary McLellan among them, have quoted the idea of Nicolas Negroponte, according to whom the time we live in is digital, with the educational implication which are not of technological, but of human mature. Among the quotations of trends the authoress has stated, mental processes comprehension within the constructivism frameworks seems to be especially important. McLellan emphasizes the importance of Piaget' cognitive development stages for the grounds of constructivism. Other authors, like, for example Severy, have also accepted that learning takes place and develops through the interaction with the man's environment, through the investigation of the environment and construction of knowledge gained through the experiences. Such constructivistic perspective on learning has implications for the use of the media as well as for the design of a curriculum. The paradigm of learning in which a learner learns, creating one's own construct in one's own way (it is necessary for learning situation to be adjusted to this perspective), implies an individual equipped with creative means in order to open up possibilities for the construction of one's own knowledge representation.

Severy, who has already been mentioned, has suggested three basic propositions to be taken into consideration when creating previously mentioned implied environment.

- understanding is in our interactions with the environment... we cannot talk about what has been learnt apart from what was learnt; multimedia curricula have to be in adequate context, setting, having in mind that, according to constructivism, learning is contextual.

- cognitive conflict or complex is a stimulus for learning and determines the organization and the nature of what has been learn; the latter principle put special emphasis on the nature of learning based on a problem;

- knowledge is formed in a social context; knowledge evolves through social negotiations and evaluation of the sustainability of individual understanding; knowledge arises out of mutual interaction in a community of those who learn; according to this, learning can and should take place in cooperative groups...

- the very advocates of the concept consciously refer to the possible difficulties in application. One of them can appear in the creation of a curriculum, since, for example, using a computer is an activity which mostly develops independently. Constructivism

\footnotetext{
${ }^{16}$ On the characteristics of allosteric and other didactic models of learning, we refer the reader to: Gojkov, G., Didaktika i postmoderna, VŠV.
} 
supporters have also pointed to the fact that individual constructions of knowledge do not have to be sustainable, correct, but it is considered that we should have in mind that constructivism does not suggest one comprehensive, egalitarian basis of knowledge, it is rather aware of the conflicting features of various perspectives (understandings...) and suggests that differences undergo some kind of refinement through interaction.

- one of the criticisms to the environments for constructivist learning frequently mentioned by the very advocates of constructivism (i.e. Jonassen), creating a resistance towards the approach is that the results of constructivistic approach will be intellectual anarchy. The defence of constructivists is based on the standpoint that this is not possible, having in mind that the environment or physical world is a subject to certain physical laws forcing knowledge to be consistent with these laws. Majority of facts in a domain is seen in a similar way by the majority of learners. A great deal of experienced knowledge is formed through a process and a product, as it has been considered by Jonassen and others, of social negotiations.

The above sketched outlines of constructivistic approach to learning are offered here not to develop reflections on constructivism as didactic paradigm according to them; our intention was not to broaden theoretical grounds for the explication of constructivistic starting points, having in mind that we believe that the reader is already familiar with its primary standpoints; our intention here was to offer several basic elements from the theoretical framework in order to get to instructional principles, supported by the authors mentioned in the text considered to be those to be build into the genera framework of a curriculum. Some of them refer to the following:

- to anchor all learning activities into a broader task or a problem: learning has to be purposeful and its purpose has to be clear to the learner;

- to support the learner in the adoption of general aim or task;

- to create an authentic task (task authenticity implies a harmony between cognitive demands and learning environment the learner is preparing him/herself for through learning - consistency);

- to create the task and the learning environment in such a way that they reflect the complexity of the setting in the real world; learning environment should not be simplified, i.e. the principles of the first cognitive phase should rather be guided so that they help the learner in a real complex environment;

- to provide the learners with the processes leading to problem solution;

- to create learning environment in such a way that it supports and challenges learner's thinking (even if the learner perceives the problem, it does not mean that any activity or a solution is adequate); a learner has to be trained to think and solve the problems in an adequate way, i.e. the learner should be able to adequately respond to stimulating environment;

- to encourage testing of ideas according to alternative views and contexts (having in mind that knowledge is socially negotiated construction, quality of someone's understanding can be determined only in the social environment where we can see whether our understanding can be adjusted to the views and the conclusions of others and whether there are viewpoints which could be usefully build into our own understanding; 
- to provide possibilities and support reflection on the learning contents and process. Self-regulatory and self-reflection skills have to become independent from the teacher.

The last principle is rather important for the title of the paper, since it refers to metacognitive abilities which, as one of the elements of the interdependence of selforganized learning and circumstances, have been focused in the paper from the angle of the awareness on one's own cognitive functioning, as well as subjective experiences or metacognitive experiences, consciously registered after difficulties in cognitive functioning (being confused, the feeling of making a mistake...) and the strategy of monitoring and managing one's own cognition and behaviour (metacognitive decisions on what should be taken care of, what should be well checked, what is the direction in which solution should be searched for, etc).

The fact that our intention was to deal with closer observations of metacognition, as one of the significant points in the guidelines of learning in constructivism, was another reason to briefly outline the above mentioned principles. For our dealing with metacognition in the paper it should be mentioned that it would be possible to adopt Sternberg's view on the meta-components:

- decision making on what is the essence of the problem,

- the choice of the ways of pieces of information presentation,

- the choice of strategies for components combining,

- the choice of the focus of attention,

- monitoring of the course of problem solving,

- sensitivity to extrinsic feedback, etc.

According to Sternberg, these meta-components represent the process permeating the course of problem solving; some of them are a priori to the problem and it is through them that operationalization of complex self-regulating mechanisms is carried out, used by a subject to manage one's own cognitive activity at parallel level. This is the reason why Sternberg considers metacognitive components to be the central process in intellectual functioning. This is worth mentioning here that the views on metacognition are heading towards it being determined as cognitive phenomenon of a higher rank cognition on cognition - metacognition, and that it involves intellectualization of various cognitive functions, including intellect itself. ${ }^{17}$

We consider it important to mention the way Flavell has defined metacognition, according to which it is determined as knowledge and cognition on cognitive phenomena. This is for other researchers as well significant determination of the term metacognition, having in mind that it implies the awareness of metacognition and suggests that metacognition is an awareness phenomenon, and that only within metacognition there are other phenomena "participating" (motivation, affects, etc). ${ }^{18}$

17 Sternberg, R. J. Reasoning, problem solving and intelligence in R. J. Sternberg (ed.): Handbook of human intelligence, Cambridge University Press in Sternberg, R. J., Toward a triarchic theory of human intelligence, The Behavioural and brain sciences, 7, 1984.

${ }^{18}$ Levkov, Lj, Intelektualni razvoj, metakognicija i škola, in: Saznavanje i nastava, Institut za pedagoška istraživanja, Belgrade, 1995. 
It is also important for the issue we are trying to consider that many hold that metacognition is a secondary result of experience and learning, implying further its complex psychological structure - multidimensional, as well as previous barrenness of the attempts to "seize" the factors influencing the courses and effects of metacognition. As a consequence, there is involvement of metacognition in the model of monitoring and regulation of cognitive activity, a mechanism further related to metacognitive experiences, as well as to the aims (tasks, problem) and strategies used in problem solving.

Interconnectedness of the components in practical functioning makes the complexity of the term, as well as its manifestation impossible "to seize". So, aware that our endeavour to empirically examine the problem will face the fact many times emphasized in relevant literature, referring to the statement that exemplary descriptions of a model do not offer more than a mere incomplete empirical grounds for description and a vague picture of integrations, we have nevertheless more than once undertaken empirical research on metacognition. It is very interesting to us in this paper, since it can help us try to more closely see the possibilities of instructional approach (ability research) to learning, considered to be of help in overcoming of the problems in the field of diagnostics, such as:

- impossibility to eliminate the influence of various types of experiences on test results, which usually discriminates the subjects with experiences not expected by the tests;

- non-resistance of classical tests to the influence of non-intellectual factors... ${ }^{19}$

And so, instructional approach, as a new research paradigm, involves the influence of metacognitive components, interweaving them into neo-Vygotskian courses of process diagnostics, while talking about self-regulation and metacognition importance, it at the same time talks about thinking development, as well as about creation of functional links between various psychological processes during development. Due to the fact that pedagogic psychology views the importance of metacognition in such a way, as well as the possibilities to influence its formation, ${ }^{20}$ it has found itself on the list of significant principles, by constructivists considered important for learning organization. Therefore it has been the subject of our previous studies. The aims of the studies have been directed towards empirical validation of constructivism as epistemological-methodological grounds, as well as the paradigm of postmodern didactics.

We would not deal further with the specific features of constructivism ${ }^{21}$ at this point, we would rather turn to what is most significant for teaching from didactic angle, like, for example:

\footnotetext{
${ }^{19}$ For further reading see: Gojkov, G., Prilozi postmodernoj didaktici, VŠV, Vršac, 2002.

${ }^{20}$ For further reading see: Stojaković, P, Istraživanja u oblasti metakognicije i njihov značaj za razvijanje efikasnih strategija i spsobnosti učenja, Pedagoška stvarnost, ,br.7-8, Novi Sad, 1998, as well as in: Gojkov, G., Vaspitanje metakognicije kao element didaktičke kompetencije nastavnika, VŠV, Šabac, Zbornik, 1995. and in: Gojkov, G., Metakognicja i strategijski transfer u diaktičkim kompetencijama nastavnika, "Inovacije u nastavi”, br. 5, Beograd, 1995.

${ }^{21}$ For further reading, see: Stojnov, D., Konstruktivizam, participativna epistemologija i konstruktivnost psiholoških kategorija, Zbornik br.30, Beograd,1998; on didactic aspect of the model
} 
- constructivism does not view knowledge as something which cannot depend on the individual angle of the learner;

- epistemological orientation of constructivists is based on participatory learning, rather than on subjective learning...

Previous statements have an influence on the modern learning theories, didactic theories and models, as well as on the tendencies in the whole educational systems in many European countries to be without much discourse copied in Serbia. Their empirical validation is yet to come; expressed by the language of constructivists, the standpoints of constructivism, considered to carry nothing more but the signs of prescriptive norms, it (formed as a construction) should only be crystallized in a social context. Empirical validation should facilitate crystallization.

We have made an attempt at searching for metacognition identity according to the findings of several empirical, i.e. explorative studies, undertaken since 1995, in order to make a step further from the basic determination, i.e. identification of metacognition as cognitive phenomenon. We were also interested in the persistent outcomes on the positive correlations between metacognitive statements and didactic instructions, supporting and leading to greater effects on criterion tasks. All this was placed within Sternberg's triarchic theory of abilities we, just like so many others, thought could explicate the combining of intellectual activities.

The essence is that, after all this, we are under impression that what at the first sight seems to be an acceptable way to consider the combining of cognitive activities actually gets out of line; it is impossible to "seize", strongly opposing to investigation; as a consequence, we did not get further than the insight that metal transformations and productions of new meanings have for the existing methodology remained an elusive specific complex of circumstances where the conditions from within encounter extrinsic conditions. Unfortunately, we could not reach a finding beyond this. How does this process take place? What is going on "behind the curtains" and how to encourage the important activities as metacognitive reactions?

Numerous objections to constructivism and attempts at reaching a point beyond it have to an extent been supported by the findings, if not directly then through drawing attention to the need to further empirically investigate them, i.e. search for different definitions of the phenomena included in the contents of constructivism (with metacognition being one of them), as well as for a different methodology, a one that might support constructivistic paradigm itself.

\section{Empirical Validation of Constructivistic Approaches to Learning in Teaching}

The findings permeating the above discussed reflections refer to the following:

Metacognitive abilities, as those elements encouraging students' autonomy, resist research; at the same time the complexity of problem solving does not allow

see: Gojkov, G., Od konstruktivizma do alosteričnog modela, Zbornik Katedre za pedagogiju, Filozofski fakultet, Novi Sad, 2002. 
simplification. The interaction between the elements and multiple relations, i.e. regulations, creates new features, and pausing at one moment leads to a change of meaning of what is being studied. We hold that this is a significant reason explaining why we have still not come to more precise determination of psychological "substance" of metacognition; furthermore, the research has not made a significant step ahead in this sense. Sternberg's triarchic theory of intellectual abilities, as theoretical framework, was in this case not sufficient and did not allow us to precisely consider the ways cognitive abilities combine. The context - problem has caused various metacognitive components, i.e. various activities students intended to undertake; they were very often not aware of them; the meta-components were vanishing and coming back, succeeding one another, combining in various ways, while it seems that they significantly depended on the context, the problem, once again confirming the unrepeatable complexity of cognitive process and the lack of power of the undertaken methodological approaches and making metacognition as a cognitive phenomenon almost impossible to seize.

The second conclusion which, from the angle of postmodern didactics, could also be considered an argument in its favour, refers to the fact that by the means of the research we have come to a statement that there are different approaches to problem solving. Some of them have at one point been complementary and at others conflicting. We should here turn to the meanings of external pieces of information a student interprets. A student has, in our case, construed, but the pieces of information coming from the setting have also been significant (interaction with new data, encouragements to modify one's own mental structure, to elaborate (reformulate), as well as the awareness of the importance of all this for the activity to be undertaken (metacognition). In other words, there is a conclusion appearing beyond all this insisting on respect of conceptual mechanism of students and interdependence of self-organization of learning and circumstances. Neither the existing didactical models, nor models of learning process study could succeed in grasping the importance of metacognition and its influence on the mobility of one's knowledge. We have in this research dealt with the aspect of conditions facilitating the modification of the existing network of conceptions. We have been searching for the elements which enable efficient self-regulation. Radical transformation of student's concept at some points was automatic, while in others it proceeded slowly, deteriorated by obstacles (previous knowledge...); at other points a whole range of convergent and redundant elements has appeared, difficult to coordinate. Consequently, the mental network, mobilized at those moments, connecting student's conceptual framework with the pieces of available information, did not go in a simple sequence of order. We are ready to accept the standpoints of those who advocate the allosteric model, according to which internal conditions encountered and combined with the external ones, not leading to the simple accumulation of new pieces of information (knowledge). Learning is not a simple accumulating process; new meaning is rather produced through mental transformations with emphasised motivational note.

The conclusions above are in favour of constructivistic approaches, theories which are in the grounds of changes in educational system. In the beginning the need to focus on individual student has been emphasised. However, we are under the impression that this research has pointed to the need to pay more attention to the setting. We have seen that the conditions facilitating learning play a significant role in problem solving. Ten types of didactic instructions have been defined which can effectively encourage 
mental abilities. We are not sure that the list of factors is exhausted, as well as the factors participating in the construction of new knowledge. Knowledge does not simply depend only on general cognitive structures, but the process of learning includes strategies, construction and deconstruction, which, being interactive processes, cannot ignore the fact that there are student's prior-conceptions and that they are, according to some views (allosteric models) an obstacle for new levels of organization of ideas; apart from this, the process of problem solving involves numerous multifunctional and multi contextual activities, resulting in mobilization of more levels of mental organization, the student is not aware of. We even think that it is not possible to succeed in an attempt to describe the courses of knowledge construction according to certain models, i.e. theories and to explain the flows underlying them. Some of the new attempts, mentioned as so called allosteric models of learning, are actually a try to go beyond constructivistic models, which do have respect for the importance of didactical setting, but its role is considered form the angle of interference with the prior-concepts.

Basic conclusions refer to the following:

- metacognitive abilities, as one of the elements encouraging students' autonomy, strongly resist investigation; neither the existing didactical models nor the models of learning process research are sufficient to consider the importance of metacognition, as well as its influence on the operability and mobility of one's knowledge.

- the conditions facilitating learning play a significant role in problem solving. (ten types of didactic instructions have been identified which can effectively encourage cognitive abilities - metacognition); knowledge does not simply depend only on general cognitive structures, but the process of learning includes strategies, construction and deconstruction, which, being interactive processes, cannot ignore the fact that there are student's prior-conceptions and that they are significant for the new levels of organization of ideas; apart from this, the process of problem solving involves numerous multifunctional and multi contextual activities, resulting in mobilization of more levels of mental organization, the student is not aware of. Finally, constructivism puts all this on the list for further validation.

\section{References} Books.

- Appignanesi, R. and C. Garratt (1995). Introducing Postmodernism. New York: Totem

- Bašlar,G., Novi naučni duh, Izdavačka knjižarnica Zorana Stojanovića, Sremski Karlovci, Novi Sad, 1991.

- Baucal, A., Kognitivno-informativni pristup kognitivnom razvoju, „Psihološka istraživanja”, br. 8, Institut za psihologiju, Beograd, 1997.

- Blankertz, H., Theorien und Modelle der Didaktik, Juventa Verlag, München, 1989.

- Blažič, M., i dr., Didaktika, Visokoškolsko središče, Novo Mesto, 2003.

- Brown, A.L., Metacognition, exsecutive control, self-regulation, and other more mysterions mechanisms; u: Weinert, F.E. i Kluwe, R.H. (eds): Metacognition, motivation and understanding, Lawrence Erlbaum Associates, Inc., Hillsdalle, New Jersey, 1987. 
- Cates, W. M. (1992). Considerations in evaluating metacognition in interactive hypermedia/multimedia instruction. Paper presented at the meeting of the American Educational Research Association, San Francisco.

- Csikszentmihalyi, M. (1998) Creativity and genius: a systems perspective, in: A. Steptoe (Ed.) Genius and mind: sllIdies of creativity and temperamell1 (London, Oxford University Press).

- Đorđević, J. (1997). Nastava i učenje u savremenoj školi, Učiteljski fakultet, Beograd.

- Đorđević, J. (2000). Reformni pedagoški pokreti u 20. veku, Učiteljski fakultet, Beograd.

- Giegel, H.I. (Ed.), Kommunikation und Konsens in modernen Gesedschaften, pp.7-17 (Frankfurt, Suhrkamp).

- Giroux, H. (1983). Mass Culture and the Rise of the New Illiteracy, in H. Giroux and D. Purple (1983) The Hidden Curriculum and Moral Education, pp.197-208.

- Giroux, H.A.: 1990, Curriculum Discourse as Postmodernist Critical Practice, Deakin University Press, Geelong, Australia.

- Glik, J., Stvaranje nove znanosti, Izvori, Zagreb, 1996.

- Gobet, F., Campitelli, G. \& Waters, A. J. (2002) Rise of human intelligence: comments on Howard (1999), Imelligence, 30, 303-311.

- Gojkov, G., A. Gojkov-Rajić i J. Prtljaga, Didaktica metakognitie, u: The 8th conference of the European council for high ability Development of Human Petential: Investmeent into our Future, Rodos, 2002

- Gojkov, G., Didaktička istraživanja u znaku samorefleksije; "Pedagoška stvarnost”, N. Sad, br. 9-10, 1997. br.3-4.

- Gojkov, G., Didaktički aspekt metakognicije darovitih, «Pedagoška stvarnost«, Novi Sad,

- Gojkov, G., Didaktika darovitih, VŠV, Vršac, 2008.god.

- Gojkov, G., Faktors stimulating the realisation of high potentialities, Zbornik radova sa skupa European Concil for High Ability (ECHA) and National Association for Able Children in Education in (NACE), NACE Reseach Centre, Westminster College, OXFORD, Great Britain,1998.god.

- Gojkov, G., Kognitivni stil u didaktici, VŠV, Vršac, 1996.

- Gojkov, G., Lični kognitivni okviri i metakognicija, Zbornik br X, VŠV, Vršac, 2004. i Didaktički pristupi podsticanju veština samoreflestivne i socijalne kompetencije, Arad, Univerzitet "Vasile Goldiš", 2004.

- Gojkov, G., Metakognicija i strategijski transfer u didaktičkim kompetencijama nastavnika, „Inovacije u nastavi”, br. 5, Beograd, 1995.

- Gojkov, G., Metakognicija u rešavanju problema darovitih (didaktički aspekt), u: Didaktični in metodični vidiki prenove in razvoja izobraževanja, Maribor, 2001.

- Gojkov, G., Metateorijske koncepcije pedagoške metodologije, VŠV, Vršac, 2006.

- Gojkov, G., Od konstruktivizma do alosteričnog modela, Zbornik Katedre za pedagogiju, Filozofski fakultet, Novi Sad, 2002.

- Gojkov, G., (2008),Didaktika i postmoderna, VŠV, Vršac,

- Gojkov, G., Primerenost teorijsko-metodološke utemeljenosti didaktičkih istraživanja, Godišnjak Filozofskog fakulteta u Novom Sadu, 2002.

- Gojkov, G., Vaspitanje metakognicije kao element didaktičke kompetencije nastavnika, VŠV, Šabac, zbornik, 1995.

- Gojkov,G., Didakticka istrazivanja u znaku samorefleksije; "Pedagoska stvarnost", N. Sad, br. 9-10,1997. 
- Gojkov,G., Metakognicija i strategijski transfer u didaktičkim kompetencijama nastavnika, »Inovacije u nastavi«,Beograd,br.5,1995.

- Gojkov,G., Metodološki problemi istraživanja darovitosti, VŠSSOV, Vršac, 2008.

- Gojkov,G.,Vaspitanje metakognicije kao elementi didaktičke kompetencije nastavnika, VŠV,Šabac,Zbornik,1995.

- Habermas, J. (1979). Communication and the Evolution of Society, trans. T. McCarthy, London: Heinemann.

- Habermas, J. (1984). The Theory of Communicative Action, Volume 1: Reason and the Rationalization of Society, translated by T. McCarthy. Boston: Beacon Press.

- htt://www.unige.ch/fapse/SSE/teachers/giordan/LDES/index.html

- http://carbon.cudenver.edu/ bwilson/postmodern.html

- http://faculty.ed.uiuc.edu/burbules/ncb/papers/construct.html

- http://pctaylor.com/publications/Handbook1998/Value/20Added.html

- http://ww.unige.ch/fapse/SSE/teachers/giordan/LDES/anglais/allosGB

- http://www.aare.edu.au/98pap/jos98386.htm

- http://www.concord.org/inti/cbe/papers/giordan learning.html

- http://www.unige.ch/fapse/SSE/teachers/giordan/L.../inform/

- http://www.unige.ch/fapse/SSE/teachers/giordan/LDES...s/inform/ publicat/arti

- Kaprara, Đ.V. i Ćervone, D., Ličnost, Dereta, Beograd, 2003.

- Kelly, G.A. (1970). A brief introduction to personal construct theory. In D. Bannister (Ed.), Perspectives in Personal Construct Theory. London: Academic Press.

- Konig, E., i Zedler, P., Teorije znanosti o odgoju, Eduka, Zagreb, 2001.

- Kostić, N., Prolegomena sociologije razaranja uma," Inovacije u nastavi", Učiteljski fakultet, Beograd, br. 4-5.

- Kron, F.W., Grundwissen Pädagogik, München, Basel: E. Reinhardt, 1996.

- Levkov, Lj., Intelektualni razvoj, metakognicija i škola u: Saznavanje i nastava, Institut za pedagoška istraživanja, Beograd, 1995.

- Mrkonjić, A. (2001). Komunikacijske paradigme u edukacijskom procesu, u: Didaktični in metodični vidiki nadaljnega razvoja izobraževanja, Maribor.

- Mušanović, M. (2001). Konstruktivistička teorija i obrazovni proces, u: Didaktični in metidični vidiki prenove in razvoja izobraževanja, Maribor.

- Palekčić, M. (2000). Diferencijalni istraživački pristupi u pedagogiji: dosezi i ograničenja, Napredak, Zagreb.

- Palekčić, M. (2001). Konstruktivizam-nova paradigma, u: Didaktični in metodični vidiki prenove in razvoja izobraževanja, Maribor.

- Palekčić, M. (2001). Teorijsko-metodološka (ne)utemeljenost didaktičkih istraživanja, U: Teorijsko-metodološka utemeljenost pedagoških istraživanja, Opatija.

- Palekčić, M., Diferencijalni istraživački pristupi u pedagogiji: dosezi i ograničenja, Napredak, Zagreb, 2000.

- Sternberg, R.J., Reaoning, problem solving, and inteligence u R.J. Sternberg (ed): Handbook of human inteligence, Cambidge University Press u: Sternberg, R.J., Tovard a trinarchic theory of human inteligence, the Bihevioral and brain sciences, 7, 1984.

- Stojaković, P., Istraživanje u oblasti metakognicije i njihov značaj za razvijanje efikasnih strategija i sposobnosti učenja, Pedagoška stvarnost, br. 7-8, Novi Sad, 1998. 
- Stojnov, D. (1998). Konstruktivizam, participativna epistemologija i konstruktivnost psiholoških kategorija, Zbornik, br.30, Institut za pedagoška istraživanja, Beograd.

Metodički obzori 6(2011)3

Izvorni znanstveni rad

UDK: 37.02

Primljeno: 9. 9. 2010.

\section{DIDAKTIČKA OGRANIČENJA KONSTRUKTIVISTIČKOG MODELA UČENJA U NASTAVI}

Prof. dr Grozdanka Gojkov Visoka škola strukovnih studija za obrazovanje vaspitača »Mihailo Palov« Vršac (Srbija); Nastavno odeljenje Učiteljskog fakulteta Beograd u Vršcu (Srbija) e-mail:ggojkov@hemo.net

\section{Re zime}

U radu će se najpre skicirati dominantne metateorijske tendencije u didaktici, kako bi se označili okviri kojima su omedjeni, a i na kojima se zasnivaju savremeni didaktički trendovi. Zatim će se pažnja usmeriti ka konstruktivističkoj perspektivi, kao epistemološkoj teoriji koja je u osnovi aktivnog učenja u nastavi, odnosno samoorganizovanog i biografski determinisanog procesa konstrukcije znanja. A, nastojaće se sagledati i didaktičke konsekvence konstruktivističke perspektive, odnosno didaktike omogućavanja. Poseban akcenat stavlja se na domete i ograničenja konstruktivizna uz argumentaciju nalaza ekplorativnih empirijskih istraživanja.

Ključne reči: didaktika omogućavanja, oganičenja konstruktivističkih modela učenja u nastavi, metakognicija 